\title{
Severe penile erosion after use of a vacuum suction device for management of erectile dysfunction in a spinal cord injured patient. Case report
}

\author{
S C LeRoy RNC MSN, J L Pryor MD* \\ Department of Urologic Surgery, PO Box 394 University of Minnesota Hospital and \\ Clinic, 420 Delaware Street SE, Minneapolis, MN 55455, USA.
}

\begin{abstract}
We report a case of severe erosion and cellulitis at the base of the penis as a result of vacuum suction device constriction bands left on for 4 hours in a spinal cord injured patient with paraplegia and hypesthesia of the genital area. All patients using vacuum suction devices need to be properly educated regarding usage and risks with adequate follow up; patients with hypesthesias and spinal cord injuries need information specifically related to their decreased or absent level of sensation. Only two out of seven vacuum suction device brochures reviewed warn of the risk to patients with decreased sensation in the penis, but none specifically address usage or risks to men with spinal cord injuries.
\end{abstract}

Keywords: cellulitis; constriction; education; impotence; spinal cord injury.

\section{Introduction}

The use of vacuum suction devices (VSDs) is the least invasive and one of the most successful method of the nonmedical therapies available for erectile dysfunction. ${ }^{1}$ The concept of an external device capable of producing an erection-like state by use of vacuum suction and penile constriction is not new. Historically, the first reports concerning VSDs date back to a US patent in $1917 .{ }^{2}$ However, it was not until 1974, when Osbon introduced the first commercial device, that the medical community gave this therapy serious consideration. The principle underlying vacuum tumescence therapy is that an erection can be produced by placing the penis in a vacuum chamber or cylinder which draws blood into the corporeal bodies. The erection is maintained by placement of a constricting elastic ring around the base of the penis; the cylinder is then removed, and the erection-like state allows for intercourse. ${ }^{3}$ The erection-like state with the constriction bands can be maintained for approximately 30 minutes according to various manufacturers. ${ }^{4-12}$

In selected patients the device is a good alternative to either surgical placement of a

*Correspondence. penile prosthesis, intracavernous injection of vasoactive drugs or sexual abstinence. ${ }^{\text {' }}$

There is little documentation on the potential adverse effects of the vacuum suction device, in particular with patients suffering from hypesthesias and spinal cord injuries. We report a case of severe penile erosion after use of a vacuum suction device for management of erectile dysfunction in a spinal cord injured patient.

\section{Case report}

A 25 year old paraplegic male (incomplete T12 secondary to a motor vehicle accident in 1985) was treated with vasoactive intracorporal pharmacotherapy (papaverine and phentolamine combination) from 1985-1988 at another clinic. After developing priapism in July 1988 he considered changing to Prostaglandin $E_{1}\left(P G E_{1}\right)$ but deferred for a VSD. The patient used the VSD from 1988 to 1992, without follow up with his urologist. He had increased the constriction bands to three to maintain an erection. In July of 1992 he used the device and fell asleep after intercourse with the three constriction bands on his penis for 4 hours. He was unable to feel his penis but noted a 'tight' sensation in his testicles. The patient noted a severe erosion around the base of the penis but did not seek immediate medical care. 
Three weeks later the patient presented to our office for $\mathrm{PGE}_{1}$ pharmacotherapy. On initial examination there was a severe erosion at the base of the penis on the ventral surface, but the site appeared to be healing well on its own. The patient was advised to return to clinic in 2 weeks for test-dosing with $\mathrm{PGE}_{1}$.

Three days later he was seen at his hometown hospital with complaints of fever, chills, mild headache and generalized myalgias. This was thought to be of viral etiology and the patient returned home. The next morning the patient noticed erythema and swelling of his penis and returned to the hospital emergency room. He was admitted for intravenous antibiotics and observation. Complete blood count, urinary analysis, blood cultures and creatinine were normal but his temperature was $102^{\circ} \mathrm{F}$ and sedimentation rate was elevated at 40 ( $\mathrm{nl}<20 \mathrm{~mm} / \mathrm{hr}$ ). The patient was transferred to the University of Minnesota Hospital with severe cellulitis of the penis that extended to the scrotum. After 5 days of antibiotic therapy and observation he was discharged on oral antibiotics and Neosporin cream to the base of the penis (Fig 1).

On $9 / 10 / 92$ the patient was seen in follow up and was doing well with slight swelling of the penis and scrotum. The patient was scheduled to return to clinic when the swelling was completely resolved to initiate therapy with $\mathrm{PGE}_{1}$.

\section{Discussion}

No serious side effects from use of a VSD had been reported until 1990 when a case of linear skin necrosis was reported in a 28 year old male paraplegic suffering from analgesia

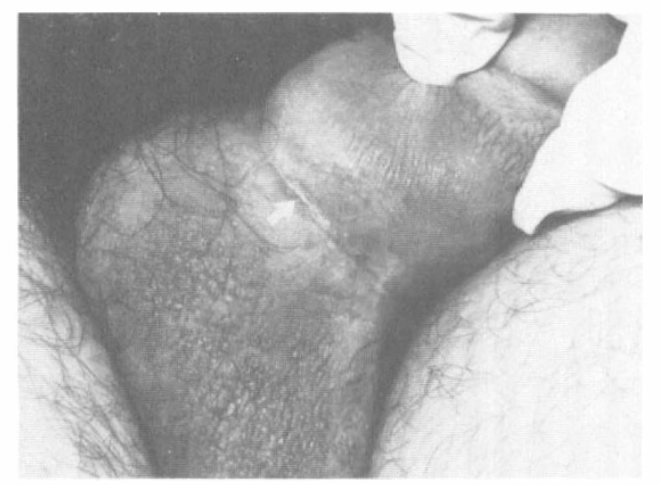

Figure 1 Annular-like erosion at the base of the penis after 5 days of antibiotic therapy. and hypesthesia from T10 downward, neurogenic bladder symptoms and erectile dysfunction for 7 years. ${ }^{13}$ The patient had used the device three times daily for 3 consecutive days. Five days after prescribing the negative pressure device a linear skin necrosis developed on the penis at the site of the rubber band. After discontinuing use of the device the skin necrosis healed, leaving a hypertrophic scar. The patient was not aware that the frequent use of the negative pressure device in combination with the silicone constricting band was damaging the skin. The authors recommended that patients with hypesthesias should be warned about frequent use of the device and should be instructed to routinely observe their skin and maintain good skin care. They also recommended that patients with sensory loss should not use the smaller constriction bands. ${ }^{13}$

It is interesting to note that of the vacuum suction devices outlined in Table $\mathrm{I}$, the $\mathrm{E} / \mathrm{P}$ System (NuMedTec Inc, Illinois) and Catalyst ${ }^{\mathrm{TM}}$ Vacuum System (Dacomed Corporation, Minneapolis) brochures are the only ones to speak of risks to men with poor sensation in the penis (eg patients with spinal cord injuries). However, none of the brochures have specific recommendations on usage of these devices by patients with spinal cord injuries.

The VSD is considered a safe treatment for patients with erectile disorders if it is initiated with proper education regarding usage and risks, and appropriate follow up. We recommend follow up after 1 month of use and then that the patient should be seen annually thereafter. If there are any questions or concerns, the patient is encouraged to call at any time. In educating patients, they should be advised to report to their physicians if they are unable to maintain an erection with two constriction bands, and are specifically instructed not to use more than two bands at any time. Observation of the skin around the base of the penis should be reinforced as a daily routine for all patients, especially those with decreased or absent penile sensation. Patients are taught to remove the constriction bands immediately after intercourse or masturbation.

There is no doubt the VSD is used safely 
Table I Vacuum suction devices and warnings by manufacturer

\begin{tabular}{|c|c|c|}
\hline Vacuum suction device & Manufacturer & Warnings \\
\hline E/P System ${ }^{a}$ & $\begin{array}{l}\text { NuMedTec Inc, Vernon Hills } \\
\text { Illinois }\end{array}$ & $\begin{array}{l}\text { Remove rings within } 30 \\
\text { minutes; do not use while } \\
\text { under the influence of alcohol; } \\
\text { do not use if poor sensation in } \\
\text { the penis; do not fall asleep } \\
\text { with rings on. }\end{array}$ \\
\hline $\begin{array}{l}\text { Mentor (Touch }{ }^{\mathrm{TM}} \text {, Piston } \\
\text { Response }^{\mathrm{TM}} \text { ) }\end{array}$ & $\begin{array}{l}\text { Mentor Corporation, Santa } \\
\text { Barbara, California }\end{array}$ & $\begin{array}{l}\text { Remove rings within } 30 \\
\text { minutes; do not fall asleep with } \\
\text { rings on. }\end{array}$ \\
\hline Pos-T-Vac ${ }^{\mathrm{TM}}$ & $\begin{array}{l}\text { Pos-T-Vac }{ }^{\mathrm{TM}} \text { Inc, Dodge City, } \\
\text { Kansas }\end{array}$ & $\begin{array}{l}\text { Do not wear rings for more } \\
\text { than } 20 \text { - } 30 \text { minutes; do not fall } \\
\text { asleep with rings on; do not } \\
\text { wear rings while intoxicated; } \\
\text { wear the rings only for several } \\
\text { minutes before and after } \\
\text { lovemaking. }\end{array}$ \\
\hline SCP $2000 / 3000$ & $\begin{array}{l}\text { Smith Collins Pharmaceutical } \\
\text { Inc, Westchester, Pennsylvania }\end{array}$ & $\begin{array}{l}\text { Do not wear rings for more } \\
\text { than } 30 \text { minutes at a time; do } \\
\text { not fall asleep with rings on the } \\
\text { penis. }\end{array}$ \\
\hline $\begin{array}{l}\text { The Catalyst }{ }^{\mathrm{TM}} \text { Vacuum } \\
\text { System }^{\mathrm{a}}\end{array}$ & $\begin{array}{l}\text { Dacomed Corporation } \\
\text { Minneapolis, Minnesota }\end{array}$ & $\begin{array}{l}\text { Do not wear rings for more } \\
\text { than } 30 \text { minutes, do not fall } \\
\text { asleep with rings on the penis; } \\
\text { men with medical conditions } \\
\text { causing decreased feeling in } \\
\text { the genital organs are to use } \\
\text { the device with caution. }\end{array}$ \\
\hline ErecAid $^{\mathrm{R}}$ & $\begin{array}{l}\text { Osbon Medical Systems Ltd } \\
\text { Augusta, Georgia }\end{array}$ & $\begin{array}{l}\text { Do not go to sleep with rings } \\
\text { on the penis; do not use if } \\
\text { under the influence of alcohol } \\
\text { or any drug that might prevent } \\
\text { safe removal of rings within } 30 \\
\text { minutes of placement; } \\
\text { extended use of rings can cause } \\
\text { discomfort and permanent } \\
\text { damage. }\end{array}$ \\
\hline $\mathrm{VED}^{\mathrm{R}}$ & $\begin{array}{l}\text { Mission Pharmacal Company, } \\
\text { San Antonio, Texas }\end{array}$ & $\begin{array}{l}\text { Do not leave rings on for over } \\
30 \text { minutes; remove rings if } \\
\text { painful to penis. }\end{array}$ \\
\hline
\end{tabular}

aVSDs with warnings to men with decreased sensation to their genitals.

and is beneficial for many patients with erectile dysfunction. It is our intent to continue this mode of therapy but to have our patients, particularly those with hypesthesias, follow the above recommendations in order to minimize potential problems.

\section{References}

1 Witherington R (1989) Vacuum constriction device for management of erectile impotence. J Urol 141: $320-322$.

2 Witherington R (1988) Suction device therapy in the mangement of erectile impotence. Urol Clin North Am 15: 123 . 
3 Salvatore F, Sharman G, Hellstrom W (1991) Vacuum constriction devices and the clinical urologist: an informed selection. J Urol 38: 323-327.

4 Lewis J, Sidi A. Reddy P (1991) A way to help your patients who use vacuum suction devices. Contemp Urol December: 15-24.

5 Mission Pharmacal Company (1991) Mission Vacuum Erection Device (VED $\left.D^{R}\right)$ User's Guide, San Antonio, Texas.

6 Dacomed Corporation (1991) Dacomed Corporation Catalyst ${ }^{T M}$ Vacuum System. Minneapolis, MN.

7 Mentor Corporation (1991) Mentor Vacuum Suction Device (Touch ${ }^{T M}$, Piston ${ }^{T M}$, Response ${ }^{T M}$ ). Santa Barbara, CA.

8 Osbon Medical Systems Ltd (1991) Guide to the Osbon Technique: How to use Erecaid ${ }^{R}$ System Classic, Augusta, GA.

9 Post-T-Vac ${ }^{\text {TM }}$ Inc (1991) Pos-T-Vac TM System. Dodge City, KS.

10 Moul J, McLeod D (1989) Negative pressure devices in the explanted penile prosthesis population. J Urol 142: $729-731$.

11 NuMedTec Inc (1991) E/P System, Westchester, PA.

12 Smith Collins Pharmaceutical Inc (1992) SCP 2000/3000. Vernon Hills, IL.

13 Meinhardt W, Kropman R, Lycklama A, Nijeholt A, Zwartendijk J (1990) Skin necrosis caused by use of negative pressure device for erectile impotence. J Urol 144: 983. 